\section{Diseases of Wild Animals}

THE part that apparently healthy wild animals play as the carriers of the causal agents of serious diseases in domestic animals and man has increasingly occupied the attention of workers in many parts of the world for many years. The effect of disease on populations of wild animals has not been so closely studied ; but its importance is well known to many ecologists and others. In a mimeographed paper recently issued by the Food and Agriculture Organization (McDiarmid, A., "Diseases of Free-living Wild Animals". Pp. 91. Animal Health Branch Monograph No. 1. F.A.O., Rome, 1960), Dr. McDiarmid summarizes the information available about the diseases of wild animals and lists the recent literature up to 1955 . The diseases are classified as those due to bacteria, fungi, viruses, protozoa, rickettsiæ, and neoplasms and tumours, and the author gives a brief review of what is known about each together with references to the literature. The paper is issued as a Food and Agriculture Organization "Working Paper" for eirculation to veterinarians and others in the Organization interested in the subject. It is to be hoped that it may be made available also to the many workers outside the Organization who will find it an extremely useful work of reference.

\section{Pre-History : Implements and Rock-Carvings}

THe July issue of Man contains several articles of general interest. The mystery of A. C. Carlyle and his collections from caves in the Morhana Pahar district of India has been elucidated by G. de G. Sieveking of the British Museum. It seems that many of the finds were bought by Dr. Sturge and are now in that celebrated collection at Bloomsbury. A. D. Lacaille illustrates a number of very large British Acheulean coups de poing, and a puzzling rock-carving from the Val Camonica is discussed by Dr. Anati of Paris. The site is near where the great glacial valley debouches on to the north Italian plain, and many rock-carvings there have been known for a long time. They include animals and humans treated in a conventional manner somewhat recalling the Copper Age paintings of Las Figuras in south-west Spain. The little group in question seems to indicate either a phallic or a ritual scene. The author suggests a date for this art group somewhere towards the start of the first millenium B.C. Is not this somewhat too early ? An interesting illustrated article on the Hainault scythe in England by G. E. Fussell and another on the ethnic origins of Zande office-holders are also included.

\section{Royal Meteorological Society:}

Scientific Activities Fund

Grants from this Fund are intended to be used to assist attendance at meteorological conferences, and priority will be given to members of the Royal Meteorological Society. Applications from younger meteorologists will recoive special consideration in order to give them the opportunity to present their work. Assistance may also be given in furtherance of moteorological research, or in support of a personal meteorological activity. Grants may also be made to European meteorologists who have been invited by the Society to visit Britain to give lectures or courses of lectures, or British meteorologists who have been invited to visit Europe for the same purpose. Applications, which should include details of estimated expenditure, should be forwarded to the Assistant Secretary (Scientific Activities Fund Committee), Royal Meteorological Society, 49 Cromwell Road, London, S.W.7, not later than December 15, 1960.

\section{Announcements}

The Charles Léopold Mayer Prize for 1960 of the Société de Chimie Biologique has been divided between Prof. R. Monier, Maitre de Conférences de Chimie Biologique at the Faculté des Sciences de Marseille, and Dr. M. Beljanski, maitre de recherches at the Centre National de la Recherche Scientifique, for their work on nucleic acids and nucleoproteins. The Prize, which is awarded annually, has a value of 5.000 NF.

The Palæontological Association is holding a discussion meeting on "Palæo-ecology" at the Department of Geology, the University of Glasgow, during December 16-17. Further information can be obtained from the Secretary to the Association, Dr. Gwyn Thomas, Department of Geology, Imperial College of Science and Technology, Prince Consort Road, London, S.W.7.

Commencing on January 14, 1961, Norwood Technical College is holding a course of twelve morning lectures and appropriate practical work as "An Introduction to Micro- and Semi-microchemical Methods". This course is particularly suitable for teachers, industrial and research chemists and is designed to survey the principal branches of chemistry in which small-scale methods have been successfully applied. Further information can be obtained from the head of the Chemistry Department, M. A. Fill, Norwood Technical College, Knights' Hill, West Norwood, S.E.27.

THE Bradford Chemical Society, the Plastics Institute (Yorkshire Section) and the Department of Chemical Technology of the Bradford Institute of Technology, in conjunction with the Yorkshire Council for Further Education, are jointly holding a symposium on "New Developments in Plastics" at the Bradford Institute of Technology on February 11, 1961. Further information can be obtained from the honorary secretary of the Bradford Chemical Society, R. P. Sheldon, Bradford Institute of Technology, Great Horton Road, Bradford 7.

The University of Cambridge Physical Chemistry Summer School will be held again in 1961, during August 12-19, the general topic being "Fast Reactions". Further information can be obtained from Prof. R. G. W. Norrish, Department of Physical Chemistry, University of Cambridge.

THE first international conference on "Protozoology", organized under the auspices of the Czechoslovak Academy of Sciences, will be held jointly with the thirteenth meeting of the Society of Protozoologists in Prague during August 22-30, 1961. Further information can be obtained from Dr. Norman D. Levine, College of Veterinary Medicine, University of Illinois, Urbana, Illinois (not later than March 1), or Prof. Otto Jirovec, Charles University, Viniena 7, Prague 11 (not later than April 1).

ERratum: In the communication entitled "Prolonged Survival of Human Sperm in chemically defined Media at Room Temperatures", in Nature of November 26 , p. 760 , it is stated that the $p H$ of the medium was initailly $7 \cdot 1$; this should read $7 \cdot 4$. 